\title{
INTERVAL BETWEEN SEQUENTIAL HERBICIDE TREATMENTS FOR SOURGRASS MANAGEMENT ${ }^{1}$
}

\author{
RAFAEL ROMERO MENDES ${ }^{2 *}$, HUDSON KAGUEYAMA TAKANO ${ }^{3}$, DENIS FERNANDO BIFFE ${ }^{2}$, JAMIL \\ CONSTANTIN $^{2}$, RUBEM SILVÉRIO DE OLIVEIRA JUNIOR ${ }^{2}$
}

\begin{abstract}
More than one herbicide application is usually necessary to manage glyphosate-resistant sourgrass in advanced stages of development efficiently during off-season fallow periods. The objective of this study was to determine the best interval between two sequential applications to control sourgrass, based on the number of days and tiller-height after the first treatment. Two experiments were conducted based on these criteria. Experiment 1 consisted of one application of glyphosate + clethodim $\left(1140 \mathrm{ae} \mathrm{ha}^{-1}+108 \mathrm{~g} \mathrm{ha}^{-1}\right)$ followed by glyphosate + clethodim or paraquat $\left(400 \mathrm{~g}\right.$ ai ha $\left.^{-1}\right)$ at an interval of $10,17,24,31,28$, or 45 days. Experiment 2 was conducted with the same herbicide treatments, but using the tiller-height as the criteria for the second application, which were 2-5, 6-10, 11-20, 21-30, and $>30 \mathrm{~cm}$. None of the treatments resulted in total sourgrass control during the evaluation period. Overall, treatments with glyphosate + clethodim in the second application were more efficient than paraquat. The most effective interval between sequential applications of glyphosate + clethodim was observed at 17 to 24 days. For paraquat, the best interval for the second application was 6-10 days. The most effective performances based on the tiller-height were found at 6$20 \mathrm{~cm}$ tall for glyphosate + clethodim and $6-10 \mathrm{~cm}$ tall for paraquat.
\end{abstract}

Keywords: Digitaria insularis (L.) Fedde. Tiller-height. Glyphosate. Clethodim. Paraquat.

\section{INTERVALO ENTRE APLICAÇÕES SEQUENCIAIS PARA O CONTROLE DE CAPIM- AMARGOSO}

\begin{abstract}
RESUMO - Para o manejo de capim-amargoso resistente ao glyphosate nos períodos de entressafra, existe a necessidade de mais de uma aplicação de herbicidas para o controle satisfatório. O objetivo deste estudo foi avaliar o intervalo em número de dias e altura do rebrote entre aplicações sequenciais no controle de capimamargoso perenizado. Foram realizados dois experimentos, sendo o experimento 1 consistuido pela aplicação sequencial de glyphosate + clethodim $\left(1140+108 \mathrm{~g} \mathrm{ha}^{-1}\right)$ ou paraquat $\left(400 \mathrm{~g}\right.$ i.a. ha $\left.{ }^{-1}\right)$ em intervalos de 10,17 , 24, 31, 38 ou 45 dias após a aplicação de glyphosate + clethodim $\left(1140+108 \mathrm{~g} \mathrm{ha}^{-1}\right)$. O experimento 2 foi formado pela aplicação dos mesmos tratamentos herbicidas, porém considerando a altura de rebrote como critério para a segunda aplicação, sendo 2-5, 6-10, 11-20, 21-30 ou >30 cm. Nenhum tratamento resultou em controle total das plantas durante o período de avaliação dos experimentos. De forma geral, melhores resultados são obtidos com a segunda aplicação de glyphosate + clethodim em relação ao paraquat. A segunda aplicação com glyphosate + clethodim deve ser realizada entre 17 e 24 dias após a primeira aplicação, enquanto o paraquat deve ser aplicado entre 6 e 10 dias após a primeira aplicação. Ao considerar o tamanho do rebrote das plantas na segunda aplicação, o ideal é de 6-20 cm para glyphosate + clethodim e de 6-10 cm para paraquat.
\end{abstract}

Palavras-chave: Digitaria insularis L. Fedde. Altura de rebrote. Glyphosate. Clethodim. Paraquat.

\footnotetext{
${ }^{*}$ Corresponding author

${ }^{1}$ Received for publication in $03 / 22 / 2019$; accepted in 07/05/2020.

${ }^{2}$ Agricultural Sciences Department, Universidade Estadual de Maringá, Maringá, PR, Brazil; rafaromero.mendes@gmail.com - ORCID: 0000-0003-4404-8826, denisbiffe@gmail.com - ORCID: 0000-0002-2036-3429, constantin@teracom.com.br - ORCID: 0000-0001-6610699X, rubem.oliveirajr@gmail.com - ORCID: 0000-0002-5222-8010.

${ }^{3}$ Colorado State University, Fort Collins, CO, United States of America; hudsontakano@gmail.com - ORCID: 0000-0002-8018-3868.
} 


\section{INTRODUCTION}

Sourgrass (Digitaria insularis (L.) Fedde) is a C4 species that belongs to the Poaceae family. The most apparent morphological characteristic is the hairy panicle of the inflorescence (LORENZI, 2014). Most species from the Digitaria genus exclusively reproduce from seeds, but sourgrass can also propagate vegetatively from rhizomes (GAZOLA et al., 2016). This defines sourgrass as a perennial grass that is able to grow and self-reproduce over the whole year under appropriate conditions (OREJA, FUENTE, FERNANDEZ-DUVIVIER, 2017).

In addition to the features cited above, there are other reasons why sourgrass has become one of the most troublesome weeds in South American countries. The adoption of no-till systems and reduced soil plowing (FIDALSKI; YAGI; TORMENA, 2015) have made herbicides the primary tools for sourgrass management across grain fields. Commercialized glyphosate-resistant (GR) crops such as soybean and corn have led to the increased use of this herbicide. Since 2008, GR sourgrass populations have been selected by frequent glyphosate treatments (CARVALHO et al., 2011) and surveys have shown that $57 \%$ of sourgrass populations are now GR (LÓPEZ-OVEJERO et al., 2017).

Despite the resistance problems, herbicide treatments are still the first option for sourgrass control. In pre-emergence or initial post-emergence treatments, several herbicides are efficient for sourgrass management; however, the number of options is reduced to systemic herbicides in plants with more than four tillers (eg. ACCase and EPSPS inhibitors) (GEMELLI et al., 2013). Contact herbicides such as glufosinate and paraquat can also be used to complement a previous systemic treatment (MELO et al., 2012; GEMELLI et al.,
2013).

In Brazilian grain production systems, there is a long off-season period between harvesting corn and sowing soybean (normally July to November). During this period, sourgrass infestation usually requires two to three herbicide treatments to achieve a satisfactory control level (CORREIA; ACRA; BALIEIRO, 2015). Many growers use a first application approximately 20 days before soybean sowing and a second application on the day of sowing (CONSTANTIN et al., 2009). However, this interval can be longer or shorter depending on the climate conditions, the presence of other weeds, and the logistics of the farm.

There is a lack of research showing the effect of different intervals between sequential applications for sourgrass control in the off-season. The hypothesis of this study was that the best interval between two applications would be approximately 15 days, and the final result would depend on the type of herbicide used on the second application (contact or systemic). The objective was to evaluate day intervals and tiller-height intervals on the efficiency of sourgrass control by sequential applications.

\section{MATERIAL AND METHODS}

Two field experiments were conducted between January and March 2015 (experiment 1), and between August and October 2016 (experiment 2) in Mandaguaçú City (Paraná State, Brazil). Climate conditions during the experimental period are shown in Figure 1. The climate classification in the experimental site is $c f a$ (Koppen), meaning the average temperature in the coldest month of the year is lower than $18^{\circ} \mathrm{C}$, and average temperature in the hottest month of the year is higher than $22^{\circ} \mathrm{C}$.
Experiment 1 - 2015

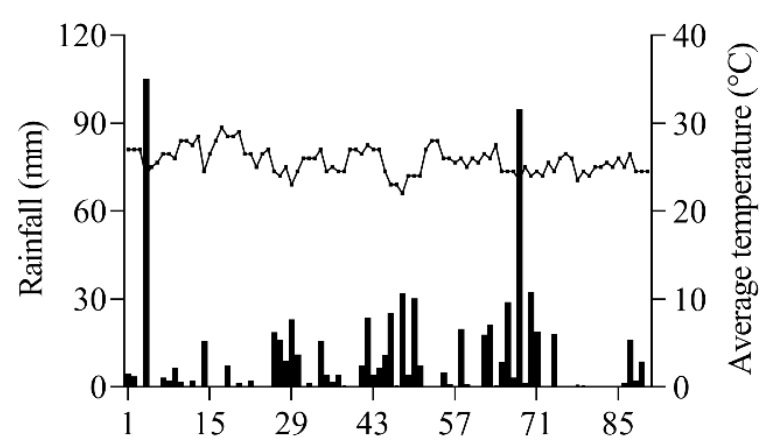

Days after the beginning of the experiment
Experiment 2 - 2016

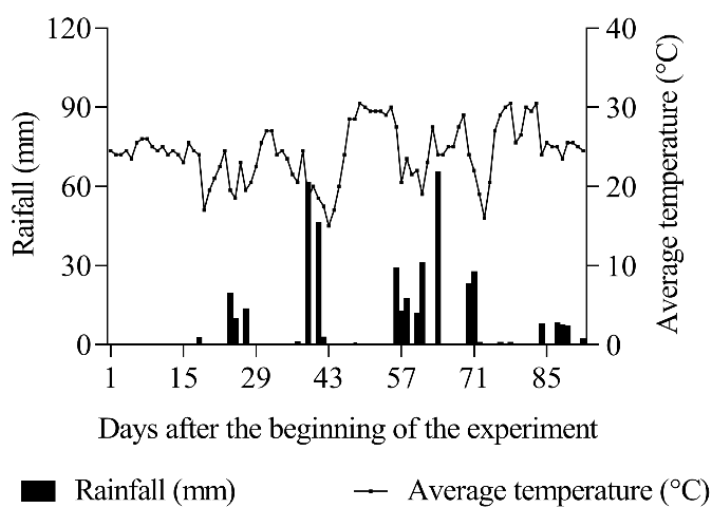

Figure 1. Meteorological data during the experimental period (INMET, 2018). 
The soil of the experimental site had a $\mathrm{pH}$ of 5.5 in $\mathrm{H}_{2} \mathrm{O}, 21 \mathrm{~g} \mathrm{dm}^{-3}$ of carbon, and a clay soil composed of $6.1 \%$ sand, $21.5 \%$ silt, and $72.4 \%$ clay. The field had been under soybean and corn crop rotation for seven years. At the beginning of the experiments, the soil was covered by corn straw remaining from the previous season. For experiment 1, corn was harvested 150 days before the start of the experiment in January. Then, corn was cultivated again after the end of experiment 1 and experiment 2 was performed 15 days after the second corn harvest (starting in August). The location was infested with 16 plants $\mathrm{m}^{-2}$ (experiment 1 ), and 14 plants $\mathrm{m}^{-2}$ (experiment 2) of sourgrass. The plants were at the flowering stage with more than 20 tillers each. Glyphosate-resistant sourgrass has been reported at the experimental site (LÓPEZ OVEJERO et al., 2017).

\section{Experiment 1}

Experiment 1 consisted of two sequential applications at different intervals (measured in days). Except for the non-treated control plots, all experimental plots were treated with glyphosate (Roundup Transorb) + clethodim (Select) at $1140 \mathrm{~g}$ ae ha ${ }^{-1}+108 \mathrm{~g}$ ai ha $^{-1}$. A factorial arrangement $(6 \times 2)$ +1 was established, where the first factor was six timing intervals between the first and second application $(10,17,24,31,38$, and 45 days). The second factor was composed of two different treatments in the second application, glyphosate + clethodim at $1140+108 \mathrm{~g} \mathrm{ha}^{-1}$ (systemic treatment) or paraquat (Gramoxone) at $400 \mathrm{~g}^{\mathrm{ai} \mathrm{ha}} \mathrm{h}^{-1}$ (contact). The additional treatments were one control without the second application (non-sequential) and a nontreated control (check).

\section{Experiment 2}

Experiment 2 consisted of two sequential applications at different tiller-height intervals. As for experiment 1 , the treatments except the check were sprayed with glyphosate + clethodim $(1140+108 \mathrm{~g}$ $\mathrm{ha}^{-1}$ ) on the same day. A factorial arrangement was designed $(5 \times 2)+2$, where the first factor was different tiller-heights at the time of the second application $(2-5,6-10,11-20,21-30,>30 \mathrm{~cm})$. These treatments were defined by measuring 50 new tillers (tillers that regrew from culm nodes) per plot every 2 days. The second factor was composed of the same two treatments at the second application: glyphosate + clethodim at $1140+108 \mathrm{~g} \mathrm{ha}^{-1}$ (systemic) or paraquat at $400 \mathrm{~g}$ ai $\mathrm{ha}^{-1}$ (contact). The additional treatments were the same as described for experiment 1 .

For both experiments, glyphosate + clethodim was used because this mixture has been used to control post-flowering sourgrass (ZOBIOLE et al., 2016). Although GR sourgrass was present in the experimental area, glyphosate associated with ACCase inhibitors in a tank mix can increase the control levels (BARROSO et al., 2014). The glyphosate + clethodim was mixed in a tank with nonionic surfactant $\left(0.2 \% \mathrm{v} \mathrm{v}^{-1}\right)$.

\section{Experimental units, sprays, and data collection}

The plots were $6 \times 4 \mathrm{~m}\left(24 \mathrm{~m}^{2}\right)$ and the evaluations were assessed in the middle of the plots, discounting $0.5 \mathrm{~m}$ on each side. For all applications, a $\mathrm{CO}_{2}$-pressurized pack back sprayer was used. The sprayer was equipped with a boom harboring five nozzles in a flat fan XR-110.02. A constant pressure of $196 \mathrm{kPa}$ was adopted. These conditions delivered an application rate of $160 \mathrm{~L} \mathrm{ha}^{-1}$. In all applications, the relative humidity was higher than $70 \%$, the air temperature was $20-25^{\circ} \mathrm{C}$, and the wind speed was lower than $2.0 \mathrm{~km} \mathrm{~h}^{-1}$.

The evaluations were: tiller height, measuring five plants per plot (four tillers per plant); and visual level of control $(0-100 \%$ scale, where zero was no symptoms and $100 \%$ was plant death, SBCPD, 1995). The evaluations were recorded at 7, 14, 21, $28,35,42$, and 49 days after the first application (DA. ${ }^{\text {st }} \mathrm{A}$ ) for experiment 1 and at $16,32,45,57,65$, and $80 \mathrm{DA} .1^{\text {st }} \mathrm{A}$ for experiment 2 . For tiller height quantification, the measurement was taken from the bud to the insertion of the first leaf.

\section{Data analyses}

A randomized complete block design was used, with four replicates per treatment. The data were subjected to ANOVA. When the interaction of the factors was significant, the means of the intervals between days (experiment 1) or tiller-height (experiment 2) were compared using Tukey's test. For the second factor (contact vs. systemic herbicide on the second application), the F test was used. To compare the additional treatments with other treatments, Dunnett's test was applied. The level of significance adopted for the ANOVA, Tukey, F, and Dunnett tests was 5\% $(\mathrm{p}>0.05)$ and the software used to analyze the data was SISVAR.

\section{RESULTS AND DISCUSSION}

\section{Day-intervals between sequential applications (experiment 1)}

A significant interaction between intervals (factor 1) and herbicide in the second application (factor 2) was found for 11 out of 14 response variables (seven for weed control and seven for tiller -height). Hence, portioning was performed for the two factors for all response variables.

At the shortest intervals between the two applications (10 and 17 DA. $1^{\text {st }} \mathrm{A}$ ), paraquat provided 
higher levels of control (>95\%) than glyphosate + clethodim after the second treatment (Figure $2 \mathrm{~A}$ and 2B). However, the levels of control decreased over time for all treatments containing paraquat. Treatments containing glyphosate + clethodim provided stable results $(>77 \%)$ (Figure $2 \mathrm{~A}$ and $2 \mathrm{~B}$ ).

$$
\text { A - } 10 \text { days }
$$

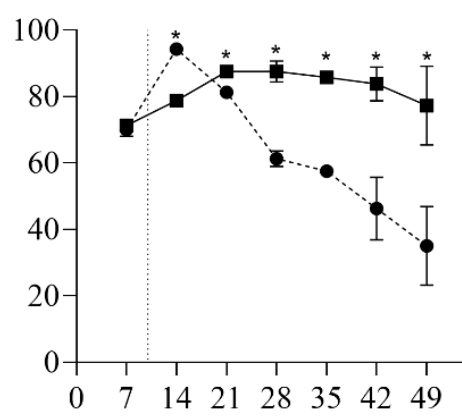

C - 24 days

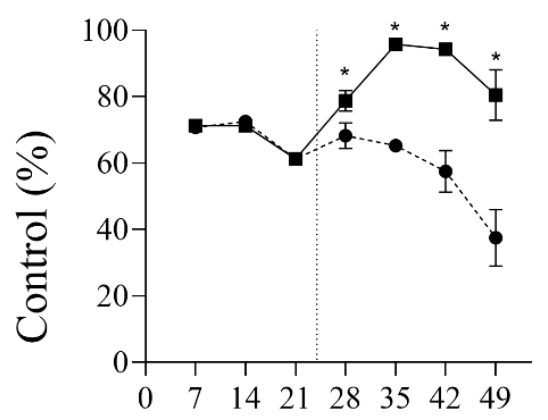

E - 38 days

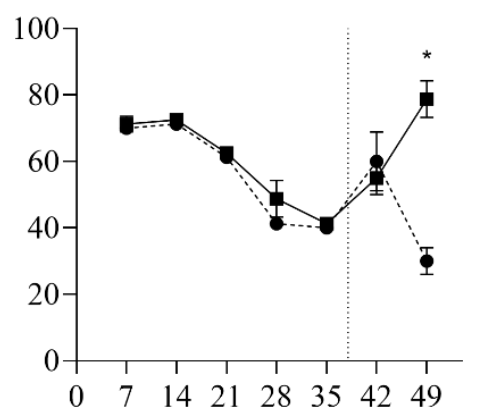

B - 17 days

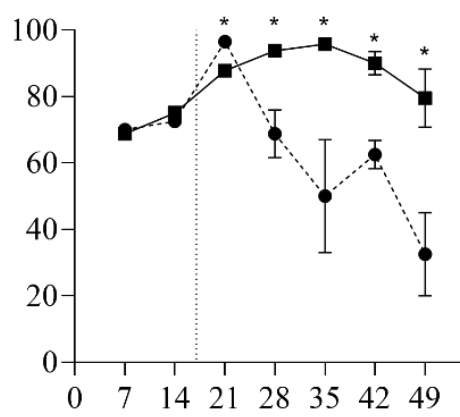

D - 31 days

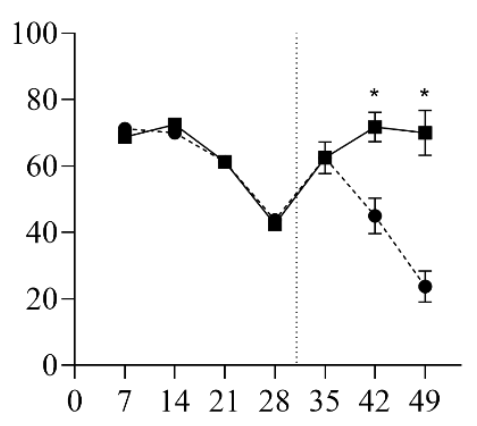

F - 45 days

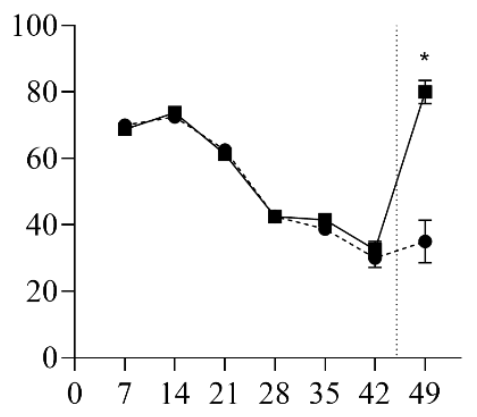

Days after the first application

Figure 2. Sourgrass control (\%) with intervals of 10 (A), 17 (B), 24 (C), 31 (D), 38 (E), and 45 (F) days between sequential applications. The second application was composed of paraquat at $400 \mathrm{~g} \mathrm{ha}^{-1}$ (squares) or glyphosate + clethodim at $1140+$ $108 \mathrm{~g} \mathrm{ha}^{-1}$ (circles). All treatments were sprayed with glyphosate + clethodim at $1140+108 \mathrm{~g} \mathrm{ha}^{-1}$ in the first application. * Significant with $\mathrm{F}$-test (5\% probability). The dashed line on the $\mathrm{x}$-axis indicates the moment of the second application, and bars represent mean \pm standard error.

The best results were observed with glyphosate + clethodim on the second application at a 24-day interval. This treatment provided more than $80 \%$ control until 49 DA. $1^{\text {st }} \mathrm{A}$. In contrast, paraquat was not effective when applied 24 days after the first application. For treatments with longer intervals between the two applications (31, 38, and 45 days), although glyphosate + clethodim conferred better results than paraquat, the best treatments did not achieve $80 \%$ control over the entire experimental period (Figure 2D, 2E, and 2F).

Glyphosate + clethodim treatments provided shorter tiller-height compared to paraquat at all 
intervals of days between the applications (Figure 3). When short intervals were adopted $(10,17$, and 24 days), there was no suppression of tiller growth over time (Figure 3A, 3B, and 3C). On the other hand, at intervals of 31,38 , and 45 days, the tillers started to regrow during the remainder of the experimental period.
A - 10 days

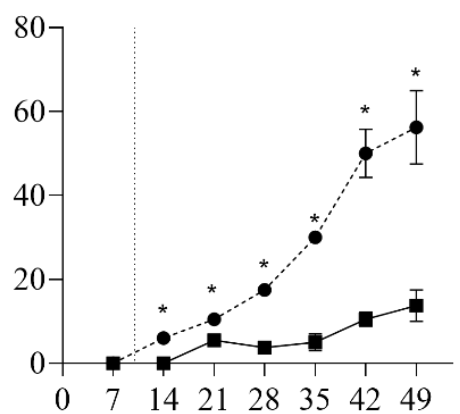

C - 24 days
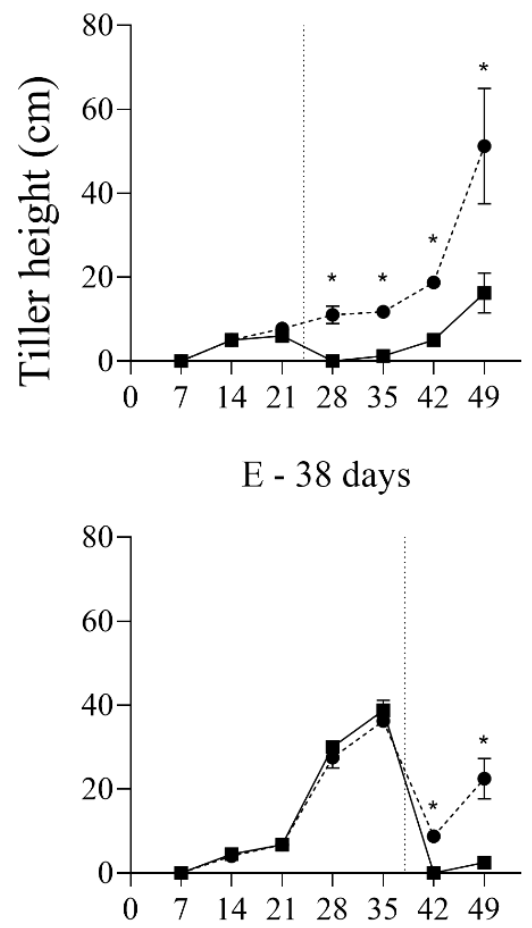

B - 17 days

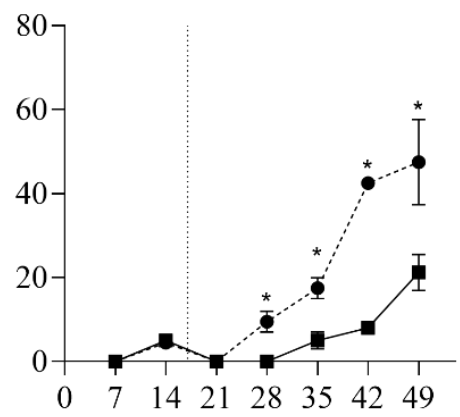

D - 31 days

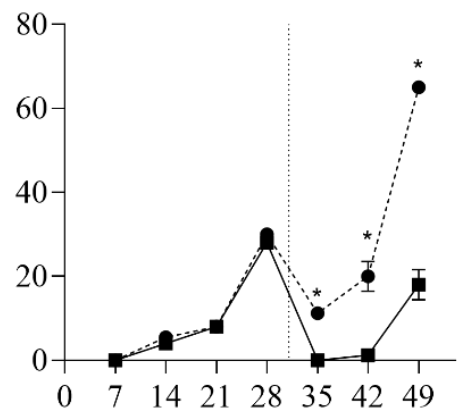

F - 45 days

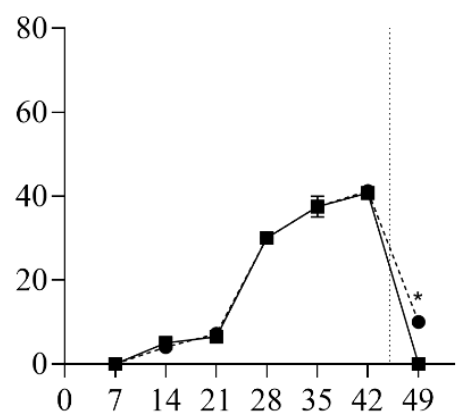

Days after the first application

Figure 3. Sourgrass tiller height (cm) with intervals of 10 (A), 17 (B), 24 (C), 31 (D), 38 (E), and 45 (F) days between sequential applications. The second application was composed of paraquat at $400 \mathrm{~g} \mathrm{ha}^{-1}$ (squares) or glyphosate + clethodim at $1140+108 \mathrm{~g} \mathrm{ha}^{-1}$ (circles). All treatments were sprayed with glyphosate + clethodim at $1140+108 \mathrm{~g} \mathrm{ha}^{-1}$ in the first application. * Significant with F-test (5\% probability). The dashed line on the $\mathrm{x}$-axis indicates the moment of the second application, and bars represent mean \pm standard error.

The best results using paraquat in the second application occurred at intervals of 10 and 17 days between sequential applications. However, results were observed up to 28 DA. $1^{\text {st }} \mathrm{A}$ (Table 1 ). The highest values using glyphosate + clethodim were observed at 17 and 24 days between sequential applications, mainly after 35 DA. $1^{\text {st }}$ A (Table 1). The response variable tiller-height was proportional to levels of control, where the shortest tiller-height values were constant at intervals of 10 to 17 days for paraquat and 17 to 24 days for glyphosate + clethodim (Table 2). 
Table 1. Sourgrass control (\%) as a function of interval in days between glyphosate + clethodim $\left(1140+108 \mathrm{~g} \mathrm{ha}^{-1}\right)$ and paraquat $\left(400 \mathrm{~g} \mathrm{ha}^{-1}\right)$ or glyphosate + clethodim $\left(1140+108 \mathrm{~g} \mathrm{ha}^{-1}\right)$.

\begin{tabular}{|c|c|c|c|c|c|c|c|c|c|c|c|c|}
\hline \multirow{3}{*}{$\begin{array}{c}\begin{array}{c}\text { Interval } \\
\text { (days) }\end{array} \\
10\end{array}$} & \multicolumn{4}{|c|}{14 DA. $1^{\text {st }} \mathrm{A}$} & \multicolumn{4}{|c|}{$21 \mathrm{DA} .1^{\text {st }} \mathrm{A}$} & \multicolumn{4}{|c|}{28 DA. $1^{\text {st }} \mathrm{A}$} \\
\hline & \multicolumn{2}{|c|}{ Paraquat } & \multicolumn{2}{|c|}{ Gly+cle } & \multicolumn{2}{|c|}{ Paraquat } & \multicolumn{2}{|c|}{ Gly+cle } & \multicolumn{2}{|c|}{ Paraquat } & \multicolumn{2}{|c|}{ Gly+cle } \\
\hline & 78.8 & $\bar{a}$ & 94.0 & $\mathrm{a}^{(+)}$ & 81.3 & $b^{(+)}$ & 87.5 & $\mathrm{a}^{(+)}$ & 61.3 & $\mathrm{a}^{(+)}$ & 87.5 & $\mathrm{bc}^{(+)}$ \\
\hline 17 & 75.0 & $\mathrm{ab}$ & 72.5 & $\mathrm{~b}$ & 96.5 & $\mathrm{a}^{(+)}$ & 87.8 & $\mathrm{a}^{(+)}$ & 68.8 & $a^{(+)}$ & 93.8 & $\mathrm{a}^{(+)}$ \\
\hline 24 & 71.3 & $\mathrm{~b}$ & 72.5 & $\mathrm{~b}$ & 61.3 & $\mathrm{c}$ & 61.3 & $\mathrm{~b}$ & 68.3 & $a^{(+)}$ & 78.8 & $\mathrm{bc}^{(+)}$ \\
\hline 31 & 72.5 & $\mathrm{~b}$ & 71.3 & $\mathrm{~b}$ & 61.3 & $\mathrm{c}$ & 61.3 & $\mathrm{~b}$ & 43.8 & $b$ & 42.5 & $\mathrm{c}$ \\
\hline 38 & 72.5 & $\mathrm{~b}$ & 70.0 & $\mathrm{~b}$ & 61.3 & $\mathrm{c}$ & 62.5 & $\mathrm{~b}$ & 41.3 & $\mathrm{~b}$ & 48.8 & $\mathrm{c}$ \\
\hline 45 & 72.8 & $\mathrm{~b}$ & 72.5 & $\mathrm{~b}$ & 62.5 & $\mathrm{c}$ & 61.3 & $\mathrm{~b}$ & 42.5 & $\mathrm{~b}$ & 42.5 & $\mathrm{c}$ \\
\hline Non-sequential & \multicolumn{4}{|c|}{73.75} & \multicolumn{4}{|c|}{58.75} & \multicolumn{4}{|c|}{42.5} \\
\hline \multirow{2}{*}{$\begin{array}{c}\text { Interval } \\
\text { (days) }\end{array}$} & \multicolumn{4}{|c|}{35 DA. $1^{\text {st }} A$} & \multicolumn{4}{|c|}{42 DA. $1^{\text {st }} \mathrm{A}$} & \multicolumn{4}{|c|}{49 DA. $1^{\text {st }} \mathrm{A}$} \\
\hline & \multicolumn{2}{|c|}{ Paraquat } & \multicolumn{2}{|c|}{ Gly+cle } & \multicolumn{2}{|c|}{ Paraquat } & \multicolumn{2}{|c|}{ Gly+cle } & \multicolumn{2}{|c|}{ Paraquat } & \multicolumn{2}{|c|}{ Gly+cle } \\
\hline 10 & 57.5 & $\mathrm{ab}^{(+)}$ & 85.8 & $\mathrm{a}^{(+)}$ & 46.3 & $\mathrm{bc}$ & 83.8 & $\mathrm{ab}^{(+)}$ & 35.0 & $a^{(+)}$ & 77.3 & $\mathrm{a}^{(+)}$ \\
\hline 17 & 50.0 & $\mathrm{~b}$ & 95.8 & $a^{(+)}$ & 62.5 & $a^{(+)}$ & 90.0 & $a^{(+)}$ & 32.5 & $a^{(+)}$ & 79.5 & $a^{(+)}$ \\
\hline 24 & 65.3 & $\mathrm{a}^{(+)}$ & 95.8 & $a^{(+)}$ & 57.5 & $a b^{(+)}$ & 94.3 & $\mathrm{a}^{(+)}$ & 37.5 & $\mathrm{a}^{(+)}$ & 80.5 & $\mathrm{a}^{(+)}$ \\
\hline 31 & 62.5 & $\mathrm{a}^{(+)}$ & 62.5 & $b^{(+)}$ & 45.0 & $\mathrm{~cd}$ & 71.8 & $\mathrm{~b}^{(+)}$ & 23.8 & $\mathrm{a}$ & 70.0 & $\mathrm{a}^{(+)}$ \\
\hline 38 & 40.0 & $\mathrm{~b}$ & 41.3 & $\mathrm{c}$ & 60.0 & $a b^{(+)}$ & 55.0 & $\mathrm{c}^{(+)}$ & 30.0 & $\mathrm{a}$ & 78.8 & $\mathrm{a}^{(+)}$ \\
\hline 45 & 38.8 & b & 41.5 & $\mathrm{c}$ & 30.0 & $\mathrm{~d}$ & 32.5 & $\mathrm{~d}$ & 35.0 & $\mathrm{a}^{(+)}$ & 80.0 & $\mathrm{a}^{(+)}$ \\
\hline Non-sequential & \multicolumn{4}{|c|}{40} & \multicolumn{4}{|c|}{30} & \multicolumn{4}{|c|}{10} \\
\hline
\end{tabular}

Means followed by the same letter in the columns are not different by Tukey's test $\left(5 \%\right.$ probability). ${ }^{(+)}$higher than nonsequential treatment by Dunnett's test ( $5 \%$ probability). DA. $1^{\text {st }}$ A: days after the first application. Gly: glyphosate, cle: clethodim.

Comparing the additional treatment (nonsequential) with the others, it was notable that the second application played an important role in achieving greater levels of control and shorter tillerheight (Tables 1 and 2).

Table 2. Sourgrass tiller height $(\mathrm{cm})$ as a function of interval in days between glyphosate + clethodim $\left(1140+108 \mathrm{~g} \mathrm{ha}^{-1}\right)$ and paraquat $\left(400 \mathrm{~g} \mathrm{ha}^{-1}\right)$ or glyphosate + clethodim $\left(1140+108 \mathrm{~g} \mathrm{ha}^{-1}\right)$.

\begin{tabular}{|c|c|c|c|c|c|c|c|c|c|c|c|c|}
\hline \multirow{3}{*}{$\begin{array}{c}\begin{array}{c}\text { Interval } \\
\text { (days) }\end{array} \\
10\end{array}$} & \multicolumn{4}{|c|}{14 DA. $1^{\text {st }} \mathrm{A}$} & \multicolumn{4}{|c|}{$21 \mathrm{DA} .1^{\text {st }} \mathrm{A}$} & \multicolumn{4}{|c|}{28 DA. $1^{\text {st }} \mathrm{A}$} \\
\hline & \multicolumn{2}{|c|}{ Paraquat } & \multicolumn{2}{|c|}{ Gly+cle } & \multicolumn{2}{|c|}{ Paraquat } & \multicolumn{2}{|c|}{ Gly+cle } & \multicolumn{2}{|c|}{ Paraquat } & \multicolumn{2}{|c|}{ Gly+cle } \\
\hline & 0.0 & $\mathrm{~b}^{(-)}$ & 6.0 & $\mathrm{a}$ & 10.5 & $a^{(-)}$ & 5.5 & $\mathrm{~b}^{(-)}$ & 17.5 & $\mathrm{~b}^{(-)}$ & 3.8 & $\mathrm{~b}^{(-)}$ \\
\hline 17 & 5.0 & $\mathrm{a}$ & 4.5 & $a b$ & 0.0 & $c^{(-)}$ & 0.0 & $c^{(-)}$ & 9.5 & $c^{(-)}$ & 0.0 & $\mathrm{c}^{(-)}$ \\
\hline 24 & 5.0 & $\mathrm{a}$ & 5.0 & $a b$ & 7.8 & $a b^{(-)}$ & 6.0 & $a b^{(-)}$ & 11.0 & $c^{(-)}$ & 0.0 & $\mathrm{c}^{(-)}$ \\
\hline 31 & 4.0 & $\mathrm{a}$ & 5.5 & $\mathrm{ab}$ & 8.0 & $a b^{(-)}$ & 8.0 & $a^{(-)}$ & 30.0 & $\mathrm{a}$ & 28.0 & $\mathrm{a}$ \\
\hline 38 & 4.5 & $\mathrm{a}$ & 4.0 & $\mathrm{~b}$ & 6.8 & $\mathrm{~b}^{(-)}$ & 6.8 & $a b^{(-)}$ & 27.5 & $\mathrm{a}$ & 30.0 & $\mathrm{a}$ \\
\hline 45 & 5.0 & $\mathrm{a}$ & 4.0 & $\mathrm{~b}$ & 7.3 & $a b^{(-)}$ & 6.5 & $a b^{(-)}$ & 30.0 & $\mathrm{a}$ & 30.0 & $\mathrm{a}$ \\
\hline Non-sequential & \multicolumn{4}{|c|}{6.0} & \multicolumn{4}{|c|}{36.0} & \multicolumn{4}{|c|}{30.0} \\
\hline \multirow{2}{*}{$\begin{array}{c}\text { Interval } \\
\text { (days) }\end{array}$} & \multicolumn{4}{|c|}{35 DA. $1^{\text {st }} \mathrm{A}$} & \multicolumn{4}{|c|}{42 DA. $1^{\text {st }} \mathrm{A}$} & \multicolumn{4}{|c|}{49 DA. $1^{\text {st }} \mathrm{A}$} \\
\hline & \multicolumn{2}{|c|}{ Paraquat } & \multicolumn{2}{|c|}{ Gly+cle } & \multicolumn{2}{|c|}{ Paraquat } & \multicolumn{2}{|c|}{ Gly+cle } & \multicolumn{2}{|c|}{ Paraquat } & \multicolumn{2}{|c|}{ Gly+cle } \\
\hline 10 & 30.0 & $\mathrm{~b}^{(-)}$ & 5.0 & $\mathrm{~b}^{(-)}$ & 50.0 & $a^{(-)}$ & 10.5 & $\mathrm{~b}^{(-)}$ & 56.3 & $a b$ & 13.8 & $\mathrm{a}^{(-)}$ \\
\hline 17 & 17.5 & $c^{(-)}$ & 5.0 & $b^{(-)}$ & 42.5 & $b^{(-)}$ & 8.0 & $b^{(-)}$ & 47.5 & $\mathrm{~b}$ & 21.3 & $a^{(-)}$ \\
\hline 24 & 11.8 & $\mathrm{~d}^{(-)}$ & 1.3 & $b^{(-)}$ & 18.8 & $\mathrm{c}^{(-)}$ & 5.0 & $b c^{(-)}$ & 51.3 & $a b$ & 16.3 & $a^{(-)}$ \\
\hline 31 & 11.3 & $\mathrm{~d}^{(-)}$ & 0.0 & $c^{(-)}$ & 20.0 & $\mathrm{c}^{(-)}$ & 1.3 & $\mathrm{c}^{(-)}$ & 65.0 & $\mathrm{a}$ & 18.0 & $a^{(-)}$ \\
\hline 38 & 36.3 & $\mathrm{a}$ & 38.8 & $a$ & 8.8 & $\mathrm{~d}^{(-)}$ & 0.0 & $\mathrm{~d}^{(-)}$ & 22.5 & $\mathrm{c}^{(-)}$ & 2.5 & $b^{(-)}$ \\
\hline 45 & 37.5 & $\mathrm{a}$ & 37.5 & $\mathrm{a}$ & 41.3 & $b^{(-)}$ & 40.8 & $\mathrm{a}^{(-)}$ & 10.0 & $\mathrm{~d}^{(-)}$ & 0.0 & $c^{(-)}$ \\
\hline Non-sequential & \multicolumn{4}{|c|}{42.5} & \multicolumn{4}{|c|}{63.8} & \multicolumn{4}{|c|}{66.3} \\
\hline
\end{tabular}

Means followed by the same letter in the columns are not different by Tukey's test (5\% probability). ${ }^{(-)}$lower than nonsequential treatment by Dunnett's test ( $5 \%$ probability). DA. $1^{\text {st }} \mathrm{A}$ : days after the first application. Gly: glyphosate, cle: clethodim. 


\section{Tiller-height-intervals between sequential applications (experiment 2)}

A significant interaction between the factors (intervals vs. herbicides in the second application) was observed in 10 out of 12 response variables (six for weed control and six for tiller-height). Thus, portioning was performed for all response variables.

Treatment with glyphosate + clethodim performed better than paraquat in the second application in all tiller-heights analyzed. Paraquat did not achieve more than $63 \%$ control, while glyphosate + clethodim caused $>90 \%$ damage, especially applied when tillers were 6-10 and 11-20 $\mathrm{cm}$ tall (Figure 4B and 4C). The systemic herbicide treatment maintained high levels of control until 80 DA. $1^{\text {st }}$ A. Nevertheless, when the sequential application occurred in small tillers $(2-5 \mathrm{~cm}$ tall) or longer tillers $(21-30$ and $>30 \mathrm{~cm}$ tall), paraquat and glyphosate + clethodim were not particularly effective $(\sim 70 \%$ control $)$.
A $-2-5 \mathrm{~cm}$

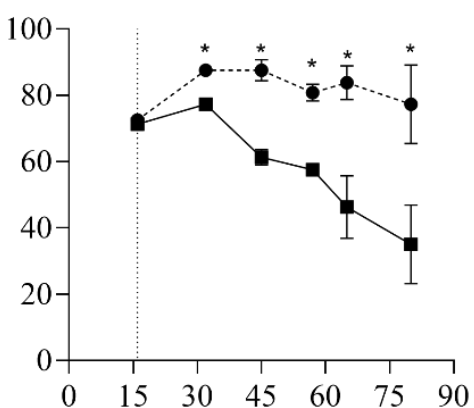

C $-11-20 \mathrm{~cm}$
B $-6-10 \mathrm{~cm}$

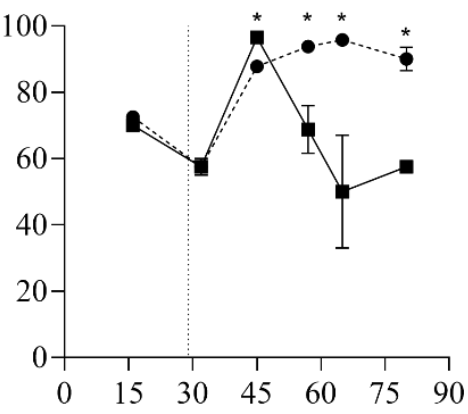

D - 21-30 cm

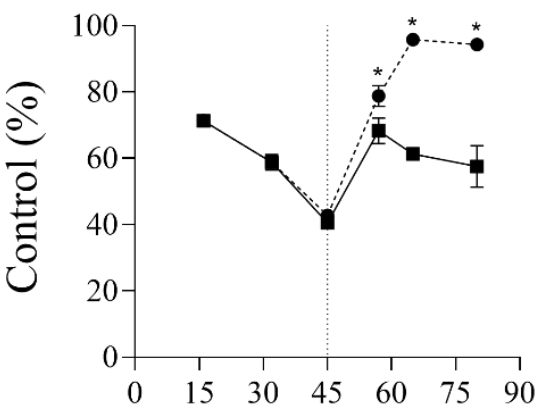

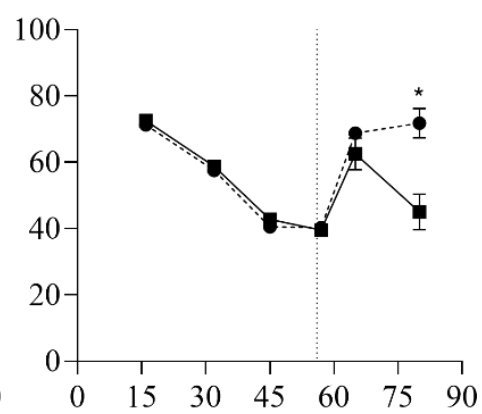

$\mathrm{E}->30 \mathrm{~cm}$

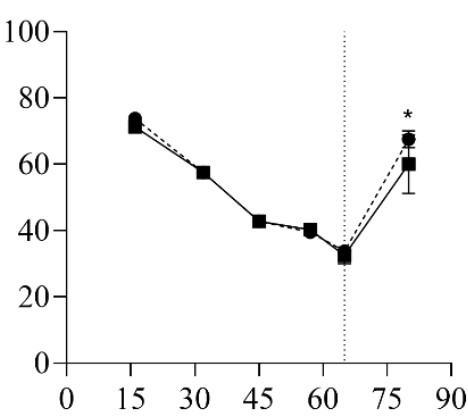

\section{Days after the first application}

Figure 4. Sourgrass control (\%) with 2-5 (A), 6-10 (B), 11-20 (C), 21-30 (D), and >30 (E) cm tiller-height interval between sequential applications. The second application was composed of paraquat at $400 \mathrm{~g} \mathrm{ha}^{-1}$ (squares) or glyphosate + clethodim at $1140+108 \mathrm{~g} \mathrm{ha}^{-1}$ (circles). All treatments were sprayed with glyphosate + clethodim at $1140+108 \mathrm{~g} \mathrm{ha}^{-1}$ in the first application. * Significant with F-test (5\% probability). The dashed line on the $\mathrm{x}$-axis indicates the moment of the second application, and bars represent mean \pm standard error. 
For all evaluations after the second application, the response variable tiller-height was taller in treatments containing paraquat than glyphosate + clethodim (Figure 5). Glyphosate + clethodim applied at tiller-height intervals of 2-5 and

$$
\text { A }-2-5 \mathrm{~cm}
$$

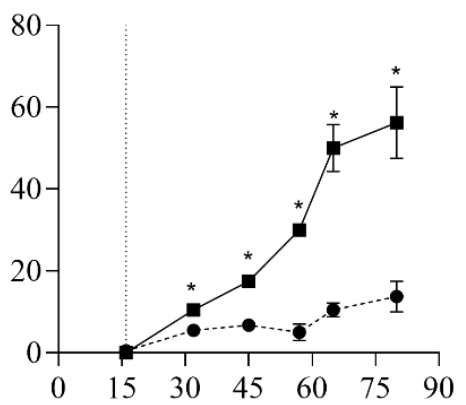

$\mathrm{C}-11-20 \mathrm{~cm}$

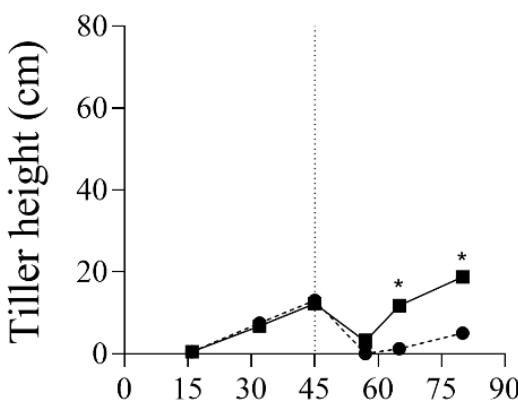

$\mathrm{E}->30 \mathrm{~cm}$
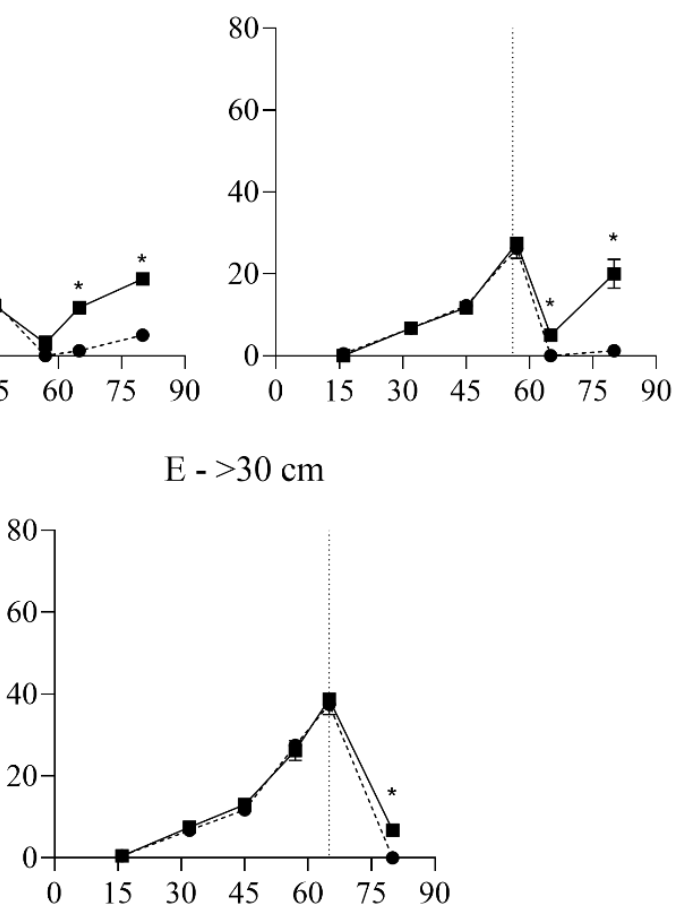

Days after the first application

Figure 5. Sourgrass tiller height (cm) with 2-5 (A), 6-10 (B), 11-20 (C), 21-30 (D), and >30 (E) cm tiller-height interval between sequential applications. The second application was composed of paraquat at $400 \mathrm{~g} \mathrm{ha}^{-1}$ (squares) or glyphosate + clethodim at $1140+108 \mathrm{~g} \mathrm{ha}^{-1}$ (circles). All treatments were sprayed with glyphosate + clethodim at $1140+108 \mathrm{~g} \mathrm{ha}^{-1}$ in the first application. * Significant with F-test (5\% probability). The dashed line on the $\mathrm{x}$-axis indicates the moment of the second application, and bars represent mean \pm standard error

There was considerable suppression of tiller regrowth in treatments applied at tiller-height intervals of 11-20 and 21-30 cm, either for paraquat or glyphosate + clethodim (Figure 5C and 5D). However, treatments composed of paraquat in the second application allowed intensive tiller regrowth on the subsequent time points compared to treatments composed of glyphosate + clethodim.
6-10 cm caused growth suppression until 80 DA. $1^{\text {st }} \mathrm{A}$, and growth did not exceed $13.8 \mathrm{~cm}$ (Figure $5 \mathrm{~A}$ and $5 \mathrm{~B}$ ). There was no growth suppression at any time point of evaluation using paraquat.

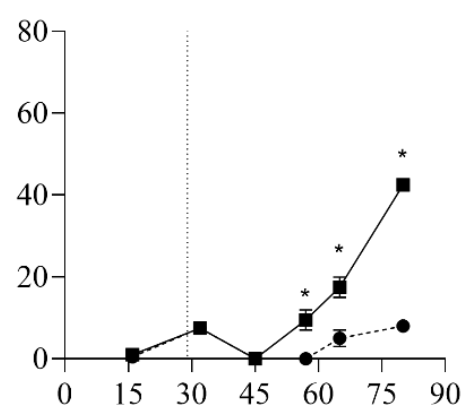

D $-21-30 \mathrm{~cm}$ 
Table 3. Sourgrass control (\%) as a function of tiller-height intervals between glyphosate + clethodim $\left(1140+108 \mathrm{~g} \mathrm{ha}^{-1}\right)$ and paraquat $\left(400 \mathrm{~g} \mathrm{ha}^{-1}\right)$ or glyphosate + clethodim $\left(1140+108 \mathrm{~g} \mathrm{ha}^{-1}\right)$.

\begin{tabular}{|c|c|c|c|c|c|c|c|c|c|c|c|c|}
\hline \multirow{3}{*}{$\begin{array}{c}\begin{array}{c}\text { Tiller-height-interval } \\
(\mathrm{cm})\end{array} \\
2-5\end{array}$} & \multicolumn{4}{|c|}{16 DA. $1^{\text {st }} \mathrm{A}$} & \multicolumn{4}{|c|}{32 DA. $1^{\text {st }} \mathrm{A}$} & \multicolumn{4}{|c|}{45 DA. $1^{\text {st }} A$} \\
\hline & \multicolumn{2}{|c|}{ Paraquat } & \multicolumn{2}{|c|}{ Gly+cle } & \multicolumn{2}{|c|}{ Paraquat } & \multicolumn{2}{|c|}{ Gly+cle } & \multicolumn{2}{|c|}{ Paraquat } & \multicolumn{2}{|c|}{ Gly+cle } \\
\hline & 71.3 & $\mathrm{a}$ & 72.5 & $\mathrm{a}$ & 77.25 & $\mathrm{a}^{(+)}$ & 87.5 & $\mathrm{a}^{(+)}$ & 61.3 & $\mathrm{~b}^{(+)}$ & 87.5 & $\overline{a^{(+)}}$ \\
\hline $6-10$ & 70.0 & $\mathrm{a}$ & 72.5 & $\mathrm{a}$ & 57.5 & $\mathrm{~b}$ & 57.5 & $\mathrm{~b}$ & 96.5 & $\mathrm{a}^{(+)}$ & 87.8 & $a^{(+)}$ \\
\hline $11-20$ & 71.3 & $\mathrm{a}$ & 71.3 & $\mathrm{a}$ & 58.75 & $\mathrm{~b}$ & 58.75 & $\mathrm{~b}$ & 40.5 & $\mathrm{c}$ & 42.8 & $\mathrm{~b}$ \\
\hline $21-30$ & 71.3 & $\mathrm{a}$ & 71.3 & $\mathrm{a}$ & 58.75 & $\mathrm{~b}$ & 57.5 & $\mathrm{~b}$ & 42.8 & $\mathrm{c}$ & 40.5 & $\mathrm{~b}$ \\
\hline$>30$ & 71.3 & $\mathrm{a}$ & 73.8 & $\mathrm{a}$ & 57.5 & $\mathrm{~b}$ & 57.5 & $\mathrm{~b}$ & 42.8 & $\mathrm{c}$ & 42.8 & $\mathrm{~b}$ \\
\hline Non-sequential & \multicolumn{4}{|c|}{71.25} & \multicolumn{4}{|c|}{61.25} & \multicolumn{4}{|c|}{42.5} \\
\hline \multirow{2}{*}{$\begin{array}{l}\text { Tiller-height-interval } \\
(\mathrm{cm})\end{array}$} & \multicolumn{4}{|c|}{57 DA. $1^{\text {st }} \mathrm{A}$} & \multicolumn{4}{|c|}{65 DA. $1^{\text {st }} \mathrm{A}$} & \multicolumn{4}{|c|}{80 DA. $1^{\text {st }} \mathrm{A}$} \\
\hline & \multicolumn{2}{|c|}{ Paraquat } & \multicolumn{2}{|c|}{ Gly+cle } & \multicolumn{2}{|c|}{ Paraquat } & \multicolumn{2}{|c|}{ Gly+cle } & \multicolumn{2}{|c|}{ Paraquat } & \multicolumn{2}{|c|}{ Gly+cle } \\
\hline $2-5$ & 57.5 & $\mathrm{~b}^{(+)}$ & 80.8 & $\mathrm{~b}^{(+)}$ & 46.3 & $a b$ & 83.75 & $\mathrm{a}^{(+)}$ & 35.0 & $\mathrm{~b}$ & 77.3 & $\mathrm{a}^{(+)}$ \\
\hline $6-10$ & 68.8 & $a^{(+)}$ & 93.8 & $\mathrm{a}^{(+)}$ & 50.0 & $\mathrm{ab}$ & 95.75 & $\mathrm{a}^{(+)}$ & 57.5 & $\mathrm{a}^{(+)}$ & 90.0 & $a^{(+)}$ \\
\hline $11-20$ & 68.3 & $a^{(+)}$ & 78.8 & $b^{(+)}$ & 61.3 & $a^{(+)}$ & 95.75 & $a^{(+)}$ & 57.5 & $\mathrm{a}^{(+)}$ & 94.3 & $a^{(+)}$ \\
\hline $21-30$ & 39.5 & $\mathrm{c}$ & 40.3 & $\mathrm{c}$ & 62.5 & $a^{(+)}$ & 68.75 & $b^{(+)}$ & 45.0 & $a b^{(+)}$ & 71.8 & $\mathrm{~b}^{(+)}$ \\
\hline$>30$ & 40.3 & $\mathrm{c}$ & 39.5 & $\mathrm{c}$ & 32.5 & $\mathrm{~b}$ & 33.75 & $\mathrm{c}$ & 60.0 & $\mathrm{a}^{(+)}$ & 67.5 & $\mathrm{~b}^{(+)}$ \\
\hline Non-sequential & \multicolumn{4}{|c|}{41.5} & \multicolumn{4}{|c|}{32.5} & \multicolumn{4}{|c|}{13.75} \\
\hline
\end{tabular}

Means followed by the same letter in the columns are not different by Tukey's test $\left(5 \%\right.$ probability). ${ }^{(+)}$higher than nonsequential treatment by Dunnett's test $\left(5 \%\right.$ probability). DA. $1^{\text {st }}$ A: days after the first application. Gly: glyphosate, cle: clethodim.

In paraquat treatments, lower values of tillerheight were observed with the second application occurring at tiller-height intervals of $6-10 \mathrm{~cm}$. Otherwise, as shown in the control response, the suppression of the regrowth of tillers was evident only at the time point after the second application (Table 4). For glyphosate + clethodim treatments, the lowest tiller height was recorded in treatments applied at tiller-height intervals of 6-10 and 11-20 cm (Table 4).

Table 4. Sourgrass tiller height $(\mathrm{cm})$ as a function of tiller-height intervals between glyphosate + clethodim $(1140+$ $\left.108 \mathrm{~g} \mathrm{ha}^{-1}\right)$ and paraquat $\left(400 \mathrm{~g} \mathrm{ha}^{-1}\right)$ or glyphosate + clethodim $\left(1140+108 \mathrm{~g} \mathrm{ha}^{-1}\right)$.

\begin{tabular}{|c|c|c|c|c|c|c|c|c|c|c|c|c|}
\hline \multirow{3}{*}{$\begin{array}{l}\text { Tiller-height-interval } \\
(\mathrm{cm})\end{array}$} & \multicolumn{4}{|c|}{16 DA. $1^{\text {st }} \mathrm{A}$} & \multicolumn{4}{|c|}{32 DA. $1^{\text {st }} \mathrm{A}$} & \multicolumn{4}{|c|}{45 DA. $1^{\text {st }} \mathrm{A}$} \\
\hline & \multicolumn{2}{|c|}{ Paraquat } & \multicolumn{2}{|c|}{ Gly+cle } & \multicolumn{2}{|c|}{ Paraquat } & \multicolumn{2}{|c|}{ Gly+cle } & \multicolumn{2}{|c|}{ Paraquat } & \multicolumn{2}{|c|}{ Gly+cle } \\
\hline & 0.0 & $\mathrm{a}$ & 0.5 & $\bar{a}$ & 10.5 & $\mathrm{a}^{(+)}$ & 5.5 & $\mathrm{~b}$ & 17.5 & $\bar{a}$ & 6.8 & $\mathrm{~b}^{(-)}$ \\
\hline $6-10$ & 1.0 & $\mathrm{a}$ & 0.5 & $\mathrm{a}$ & 7.5 & $\mathrm{~b}^{(+)}$ & 7.5 & $a^{(+)}$ & 0.0 & $\mathrm{c}^{(-)}$ & 0.0 & $\mathrm{c}^{(-)}$ \\
\hline $11-20$ & 0.5 & $\mathrm{a}$ & 0.5 & $\mathrm{a}$ & 6.8 & $\mathrm{~b}$ & 7.5 & $a^{(+)}$ & 12.3 & $\mathrm{~b}$ & 13.0 & $\mathrm{a}$ \\
\hline $21-30$ & 0.0 & $\mathrm{a}$ & 0.5 & $\mathrm{a}$ & 6.8 & $\mathrm{~b}$ & 6.8 & $a b$ & 11.8 & $\mathrm{~b}$ & 12.3 & $\mathrm{a}$ \\
\hline$>30$ & 0.5 & $\mathrm{a}$ & 0.5 & $\mathrm{a}$ & 7.5 & $\mathrm{~b}^{(+)}$ & 6.8 & $\mathrm{ab}$ & 13.0 & $\mathrm{~b}$ & 11.8 & $\mathrm{a}$ \\
\hline Non-sequential & \multicolumn{4}{|c|}{0.5} & \multicolumn{4}{|c|}{4.5} & \multicolumn{4}{|c|}{13} \\
\hline \multirow{2}{*}{$\begin{array}{l}\text { Tiller-height-interval } \\
\text { (cm) }\end{array}$} & \multicolumn{4}{|c|}{57 DA. $1^{\text {st }} \mathrm{A}$} & \multicolumn{4}{|c|}{65 DA. $1^{\text {st }} \mathrm{A}$} & \multicolumn{4}{|c|}{$80 \mathrm{DA} \cdot 1^{\text {st }} \mathrm{A}$} \\
\hline & \multicolumn{2}{|c|}{ Paraquat } & \multicolumn{2}{|c|}{ Gly+cle } & \multicolumn{2}{|c|}{ Paraquat } & \multicolumn{2}{|c|}{ Gly+cle } & \multicolumn{2}{|c|}{ Paraquat } & \multicolumn{2}{|c|}{ Gly+cle } \\
\hline $2-5$ & 30.0 & $\mathrm{a}$ & 5.0 & $\mathrm{~b}^{(-)}$ & 50.0 & $a^{(+)}$ & 10.5 & $\mathrm{~b}^{(-)}$ & 56.3 & $\bar{a}$ & 13.8 & $\mathrm{a}^{(-)}$ \\
\hline $6-10$ & 9.5 & $b^{(-)}$ & 0.0 & $\mathrm{c}^{(-)}$ & 17.5 & $c^{(-)}$ & 5.0 & $b c^{(-)}$ & 42.5 & $b^{(-)}$ & 8.0 & $a b^{(-)}$ \\
\hline $11-20$ & 3.0 & $c^{(-)}$ & 0.0 & $\mathrm{c}^{(-)}$ & 11.8 & $c^{(-)}$ & 1.3 & $c^{(-)}$ & 18.8 & $\mathrm{c}^{(-)}$ & 5.0 & $b^{(-)}$ \\
\hline $21-30$ & 27.5 & $\mathrm{a}$ & 26.3 & $\mathrm{a}$ & 5.0 & $\mathrm{~d}^{(-)}$ & 0.0 & $\mathrm{c}^{(-)}$ & 20.0 & $\mathrm{c}^{(-)}$ & 1.3 & $b^{(-)}$ \\
\hline$>30$ & 26.3 & $\mathrm{a}$ & 27.5 & $\mathrm{a}$ & 38.8 & $\mathrm{~b}$ & 37.5 & $\mathrm{a}$ & 6.8 & $d^{(-)}$ & 0.0 & $\mathrm{c}^{(-)}$ \\
\hline Non-sequential & \multicolumn{4}{|c|}{27.5} & \multicolumn{4}{|c|}{38.75} & \multicolumn{4}{|c|}{63.75} \\
\hline
\end{tabular}

Means followed by the same letter in the columns are not different by Tukey's test $\left(5 \%\right.$ probability). ${ }^{(+)}$higher or ${ }^{(-)}$lower than non-sequential treatment by Dunnett's test ( $5 \%$ probability). DA. $1^{\text {st }} \mathrm{A}$ : days after the first application. Gly: glyphosate, cle: clethodim. 
As observed in experiment 1 , it was clear that a sequential application was an essential tool compared to treatments with only one application (Tables 3 and 4).

The data compiled in this study also showed that the sequential application of glyphosate + clethodim was more effective at sourgrass control than paraquat (Figures 2, 3 and 4). The reestablishment of the tillers after paraquat treatments was verified in other research (PROCÓPIO et al., 2006; GEMELLI et al., 2013). Although the first application with systemic herbicides often provides approximately $70 \%$ control, the high amount of biomass in sourgrass clumps can intercept sprayed droplets, a phenomenon called the "umbrella effect". This prevents the herbicide from targeting the leaves when the regrowing tillers are emerging from the base of the clumps. Therefore, the effectiveness of paraquat is reduced because this herbicide requires a good leaf covering for efficient weed control (MACIEL et al., 2011). Treatments composed of clethodim can be translocated to other plant tissues even if the herbicide targets a low foliar area (MENENDEZ, DE PRADO, 1996). Another explanation for these differences between the two herbicide treatments is that paraquat has a fast uptake and action on the plant meristematic tissue, which can disrupt apical dominance and stimulate the growth of new stems from rhizomes and culm nodes (SILVA et al., 2005). However, herbicides such as clethodim have a slow action and they might be translocated to younger tissues, inhibiting the emergence of new tillers from clumps (GEMELLI et al., 2013).

The present study demonstrated that when the second application occurred soon after the first (10 days or with a tiller-height interval of $2-5 \mathrm{~cm}$ ), the final results were not satisfactory (lower than 78\%) (Tables 1, 2, 3 and 4). In these intervals, new tillers are growing but they so short that there is limited interception of sprayed droplets. When the intervals are much longer ( $>31$ days or $>21 \mathrm{~cm}$ of tiller-height interval), the new tillers have probably initialized the carbon accumulation process and cuticle formation (MACHADO et al., 2008). These physiological behaviors contribute to reducing herbicide effectiveness. Therefore, the results revealed that intermediate intervals (17 to 24 days or $6-20 \mathrm{~cm}$ of tiller-height interval) were the most effective options for systemic herbicides sprayed in a second application. In the case of paraquat, good results were found $\left(>90 \%\right.$ control) at 45 DA. $1^{\text {st }} \mathrm{A}$, with a second application at a tiller-height interval of 2-5 $\mathrm{cm}$.

The range of options examined here (systemic vs. contact with different intervals between sequential applications) revealed several alternatives that can be chosen to suit different farm needs. Gilo et al. (2016) found superior results when glyphosate
+ haloxyfop $\left(1440 \mathrm{~g}\right.$ ea ha $^{-1}+60 \mathrm{~g}$ ia ha $\left.^{-1}\right)$ followed by clethodim (108 $\left.\mathrm{g} \mathrm{ha}^{-1}\right)$ was applied at 14 day intervals compared to 7 day intervals. Zobiole et al. (2016) reported effective sourgrass control with a 35 -day interval between two applications of glyphosate + clethodim $\left(1200 \mathrm{~g} \mathrm{ha}^{-1}+240 \mathrm{~g} \mathrm{ha}^{-1}\right)$.

The recommendation of a specific interval between sequential applications must be carefully considered because the results may differ from those observed in the present study. The emergence and development of new tillers can vary because of the light, temperature, weed community, humidity, and soil nutrient conditions. For example, in experiment 1 , the treatment after a 24 day interval was applied when tillers were 6 to $7.8 \mathrm{~cm}$ tall while in experiment 2 , it took 32 days for tillers achieve the same size (treatment of $6-10 \mathrm{~cm}$ of tiller-height interval). These differences can be attributed to the lower rainfall volume in the experiment 2 period (Figure 1). Thus, it is safer to determine the best time for the second application by measuring the tillerheight rather than counting the number of days of interval.

None of the treatments provided $100 \%$ control over time. In view of this, the ideal management would be to start the herbicide applications on early stage plants (up to three tillers), which might provide effective sourgrass control with a single application (MELO et al., 2017). Moreover, pre-emergent treatments are also an important spray method to prevent sourgrass interference with crops (MONQUERO et al., 2008). Usually, the off-season period allows the rapid growth and establishment of sourgrass that requires two herbicide treatments before crop sowing and one more intervention during the crop cycle.

Good results were obtained after two applications of the same treatment (glyphosate + clethodim), but mode of action rotation is an extremely important management practice in order to mitigate herbicide resistance in sourgrass. In future studies, evaluation of alternative herbicides to replace paraquat will be needed, such as glufosinate, PPO inhibitors, or ALS inhibitors (CORREIA; DURIGAN; 2009; GEMELLI et al., 2013; MELO et al., 2012). To decrease the evolution of sourgrass resistance, integrated weed management practices are recommended rather than the use of chemical control only. Integrated weed management would include mechanical control, increased cultural control, crop rotation, and weed border control (MAROCHI et al., 2018; CORREIA; ACRA, BALIEIRO, 2015).

\section{CONCLUSIONS}

The combination of glyphosate + clethodim

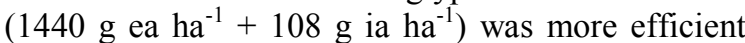
for sourgrass control than paraquat (400 $\left.\mathrm{g} \mathrm{ha}^{-1}\right)$, 
when sprayed in sequential applications. The most appropriate interval for paraquat treatment in the second application was 17 days or $6-10 \mathrm{~cm}$ tillerheight interval. The best option for two sequential glyphosate + clethodim treatments was 17 to 27 day intervals or up to $20 \mathrm{~cm}$ of tiller-height.

\section{REFERENCES}

BARROSO, A. A. M. et. al. Interação entre herbicidas inibidores da ACCase e diferentes formulações de glyphosate no controle de capimamargoso. Planta Daninha, 32: 619-627, 2014.

CARVALHO, L. B. et al. Detection of sourgrass (Digitaria insularis) biotypes resistant to glyphosate in Brazil. Weed Science, 59: 171-176, 2011.

CONSTANTIN, J. et al. Sistemas de dessecação antecedendo a semeadura direta de milho e controle de plantas daninhas. Ciência Rural, 39: 971-976, 2009.

CORREIA, N. M.; ACRA, L. T.; BALIEIRO, G. Chemical control of different Digitaria insularis populations and management of a glyphosateresistant population. Planta Daninha, 33: 93-101, 2015.

CORREIA, N. M.; DURIGAN, J. C. Manejo químico de plantas adultas de Digitaria insularis (L.) Fedde com glyphosate isolado e em mistura com chlorimuron-ethyl ou quizalofop-P-tefuril em área de plantio direto. Bragantia, 68: 689-697, 2009.

FIDALSKI, J.; YAGI, R.; TORMENA, C. A. Revolvimento ocasional e calagem em latossolo muito argiloso em sistema plantio direto consolidado. Revista Brasileira de Ciência do Solo, 39: 1483-1489, 2015.

GAZOLA, T. et al. Características biológicas de Digitaria insularis que conferem sua resistência à herbicidas e opções de manejo. Científica, 44: 557$567,2016$.

GEMELLI, A. et al. Estratégias para o controle de capim-amargoso (Digitaria insularis) resistente ao glyphosate na cultura milho safrinha. Revista Brasileira de Herbicidas, 12: 162-170, 2013.

GILO, E. G. et al. Alternatives for chemical management of sourgrass. Bioscience Journal, 32: 881-889, 2016.

INSTITUTO NACIONAL DE METEOROLOGIA INMET. Dados meteorológicos. Disponível em: $<$ http://www.inmet.gov.br/portal/index.php? $\mathrm{r}=\mathrm{estacoes} /$ estacoesConvencionais $>$. Acesso em: 12 set. 2018 .

LÓPEZ OVEJERO, R. F. et al. Frequency and dispersal of gliphosate-resistant sourgrass (Digitaria insularis) populations across Brazilian agricultural production areas. Weed Science, 65: 285-294, 2017.

LORENZI, H. Manual de identificação e controle de plantas daninhas. 7. ed. Nova Odessa, SP: Instituto Platarum, 2014. $379 \mathrm{p}$.

MACHADO, A. F. L. et al. Caracterização anatômica de folha, colmo e rizoma de Digitaria insularis (L.) Fedde. Planta Daninha, 26: 1-8, 2008.

MACIEL, C. D. G. et al. Eficiência de paraquat e MSMA isolados e associados a adjuvantes no manejo de plantas daninhas. Global Science and Technology, 4: 70-81, 2011.

MENENDEZ, J.; DE PRADO, R. Diclofop-methyl cross-resistance in a chlorotoluron-resistant biotype of Alopecurus myosuroides. Pesticide Biochemistry and Physiology, 56: 123-133, 1996.

MAROCHI, A. F. A. et al. Managing glyphosateresistant weeds with cover crop associated with herbicide rotation and mixture. Ciência e Agrotecnologia, 42: 381-394, 2018.

MELO, M. S. C. et al. Alternativas de controle químico de capim-amargoso resistente ao glyphosate, com herbicidas registrados para as culturas de milho e algodão. Revista Brasileira de Herbicidas, 16: 206-215, 2017.

MELO, M. S. C. et al. Alternativas para o controle químico de capim-amargoso (Digitaria insularis) resistente ao glyphosate. Revista Brasileira de Herbicidas, 11: 195-203, 2012.

MONQUERO, P. A. et al. Eficiência de herbicidas pré-emergentes após períodos de seca. Planta Daninha, 26: 85-193, 2008.

OREJA, F. H.; FUENTE, E. B.; FERNANDEZDUVIVIER, M. E. Response of Digitaria insularis seed germination to envirolnamental factores. Crop and Pasture Sciences, 68: 45-50, 2017.

PROCÓPIO, S. O. et al. Eficácia de imazethapyr e chlorimuron-ethyl em aplicações de pré-semeadura da cultura da soja. Planta Daninha, 24: 467-473, 2006.

SILVA, A. C. et al. Análise de crescimento de Brachiaria brizanta submetida a doses reduzidas de fluazifop-p-butil. Planta Daninha, 23: 85-91, 2005.

SOCIEDADE BRASILEIRA DA CIÊNCIA DAS 
PLANTAS DANINHAS - SBCPD. Procedimentos para instalação, avaliação e análises de experimentos com herbicidas. 1. ed. Londrina, PR: SBCPD, 1995. $42 \mathrm{p}$.

ZOBIOLE, L. H. S. et al. Controle de capimamargoso perenizado em pleno florescimento. Revista Brasileira de Herbicidas, 15: 157-164, 2016. 